\title{
TO ORDER OR NOT TO ORDER REINSTATEMENT AS A REMEDY FOR CONSTRUCTIVE DISMISSAL
}

Introduction

An employment relationship can be terminated by either the employer or the employee. Termination by the employee is referred to as resignation (Grogan Workplace Law 12ed (2017) 143; Basson, Christianson, Garbers, Le Roux and Strydom Essential Labour Law 6ed (2017) 100), and termination by the employer is referred to as dismissal and is a common way in which an employment relationship is terminated (Le Roux and Van Niekerk South African Law of Unfair Dismissal 1ed (1994) 83). Dismissal is also the most serious and drastic disciplinary penalty that an employer may impose against the employee (Grogan Workplace Law 140; Basson et al Essential Labour Law 132). Under common law, an employee does not have protection against unfair dismissal, the main focus being on the lawfulness of the termination and not the fairness of the termination of the contract (Basson et al Essential Labour Law 97). However, under the Labour Relations Act 66 of 1995 (LRA), the employee has the right not to be unfairly dismissed or subjected to an unfair labour practice (s 185 of the LRA).

In terms of section 186(1)(a) of the LRA, dismissal may take place with or without notice. Section 37 of the Basic Conditions of Employment Act 75 of 1997 stipulates that notice for the termination of an employment contract should be made in writing unless the employee is illiterate, in which case oral notice will be sufficient. Dismissal without notice is called summary or instant dismissal (Basson et al Essential Labour Law 127). Although the employer may naturally give the employee notice informing him or her about the termination of the contract, in terms of section 186(1)(e) of the LRA, the employee may also terminate the relationship but allege that the termination was due to the employer who made continued employment intolerable. This type of termination of employment is called "constructive dismissal". Section 186(1) of the LRA provides as follows:

"'Dismissal' means that-

$\cdots$

(e) an employee terminated a contract of employment with or without notice because the employer made continued employment intolerable for the employee."

Although it is the employee who terminates the employment relationship, in this instance, the action is regarded as a dismissal and not a normal resignation by the employee (Grogan Workplace Law 152; Basson et al Essential Labour Law 105; Du Toit, Godfrey, Cooper, Giles, Cohen, 
Conradie and Steenkamp Labour Relations Law: A Comprehensive Guide 6ed (2015) 430). A dismissal is either fair or unfair depending on surrounding circumstances and on compliance with both substantive and procedural requirements (s 188(1) of the LRA). In case of an unfair dismissal, section 193(1) of the LRA provides for the following remedies: reinstatement, re-employment and compensation. However, the discussion in this analysis focuses only on reinstatement and determines whether it is an appropriate remedy for constructive dismissal given that termination of the contract takes place because of the employer's intolerable conduct, leaving the employee with no other option but to resign. The discussion considers the concept of constructive dismissal, and reinstatement as a remedy for constructive dismissal in South Africa, and briefly looks at the position in the United Kingdom (UK).

\section{Constructive dismissal in South Africa}

The concept of constructive dismissal was developed by the Industrial Court, but introduced into legislation by the LRA (see Du Toit et al Labour Relations Law 430; Jooste $v$ Transnet Ltd t/a SAA (1995) 5 BLLR 1 (LAC) 7-8). Constructive dismissal occurs when the employee terminates the employment contract with or without notice because the employer made continued employment intolerable for the employee (s 186(1)(e) of the LRA; Grogan Workplace Law 152). Determining whether constructive dismissal has occurred involves a two-fold enquiry. The first question is whether, but for the employer's conduct, the employee intended to resign. If the answer is in the affirmative, then there is no constructive dismissal. However, if the answer is negative, the question that follows is whether the employer's conduct amounted to constructive dismissal (Du Toit et al Labour Relations Law 430).

It must be highlighted that there is no specific provision in the LRA regarding what conduct by the employer will be regarded as intolerable for purposes of constructive dismissal. It is therefore up to the courts to determine whether there was indeed constructive dismissal (see Jooste $v$ Transnet supra 4; Du Toit et al Labour Relations Law 430). The following are examples of employer conduct that has been accepted by courts as rendering an employment relationship intolerable: unlawful deductions from an employee's salary (Small v Noella Creations (1986) 7 ILJ 614 (IC)); the offer of an alternative position at greatly reduced salary (Mhlambi v CCMA (2006) 27 ILJ 814 (LC)); and sexual and other forms of harassment (Aarons $v$ University of Stellenbosch (2003) 24 ILJ 1123 (LC)). The onus is on the employee who alleges constructive dismissal to prove that the employer, through its actions or omissions, indeed dismissed the employee. The employee must prove the following elements: that he or she has resigned; that the employer caused his or her working conditions to be intolerable; and that it was the conduct of the employer that rendered continued employment intolerable for the employee (see Eagleton $v$ You Asked Services (Pty) Ltd (2009) 30 ILJ 320 (LC) par 22; Solid Doors (Pty) Ltd v Commissioner Theron (2004) 25 ILJ 2337 (LAC)). The employee must also objectively establish that the situation has become so unbearable that he or she cannot be expected to work any longer. An evaluation in this regard must be made 
from the perspective of a reasonable person in the position of the employee (see Johnson $v$ Rajah NO (JR33/15) [2017] ZALCJHB 25 par 50 and 51; Smithkline Beecham (Pty) Ltd v CCMA (2000) 21 ILJ 988 (LC) par 38). The employee must exhaust all possible remedies before resigning (Van Niekerk, Smit, Christianson, McGregor and Van Eck Law@work 4ed (2018) 248; see also Mafomane v Rustenburg Platinum Mines (Pty) Ltd [2003] 10 BLLR 999 (LC)). Each of the above elements is discussed in detail below.

\section{The employee must have resigned}

Constructive dismissal is different from an ordinary dismissal by the employer because it is initiated by the employee who alleges that the employment relationship with the employer has become intolerable (SALSTAFF obo Bezuidenhout v Metrorail [2001] 9 BALR 926 (AMSSA)). It is the employee who terminates the employment contract. In the termination of the employment contract, it is however not necessary for the employee to resign formally as constructive dismissal can be established even where the employee has absconded from employment (Grogan Workplace Law 152). This termination of an employment contract may be with or without notice by the employee. However, notice of termination of the employment contract by an employee is a unilateral act which, once given, cannot be withdrawn unilaterally without the employer's consent (see University of the North $v$ Franks (2002) 8 ILJ 1252 (LAC); Wiltshire v University of the North (2005) 26 ILJ 2440 (LC)). Repudiation of the contract by the employer and its acceptance by the employee will also be regarded as a termination of the employment contract or dismissal by the employer (Du Toit et al Labour Relations Law 430). Repudiation may be explained as any behaviour by a party to a contract indicating that he or she may not honour the obligations under the contract (Christie The Law of Contract in South Africa 5ed (2006) 514; see also Schlinkmann v Van der Walt 1947 (2) SA 900 (E) 919).

\section{The employer caused the employee's working conditions to be intolerable}

In the case of constructive dismissal, the termination of an employment contract by the employee is deemed to have taken place involuntarily as the employer is regarded as the actual cause of the termination. The termination takes place owing to the employer's conduct. In other words, the employer, actively or by omission, must have brought pressure to bear upon the employee and the employee must have been unable to put up with it (Basson et al Essential Labour Law 103). It is important that there be a connection or causal link between the employee's resignation and the intolerable condition caused by the employer (see Van der Westhuizen $v$ Transnet (Esselenpark) (2000) 9 BALR 1077 (CCMA); SALSTAFF v Swiss Port SA (Pty) Ltd (2003) 3 BLLR 295 (LC); Conti Print CC v CCMA [2015] 9 BLLR 865 (LAC)). There must have been unfair or wrongful conduct by the employer that forced the employee to resign. It is not necessary for the employer's conduct to have been intentional (Van der Riet $v$ Leisurenet (1998) 5 BLLR 471 (LAC) 43; Du Toit et al Labour Relations Law 431). Generally, the employer must have at least been aware of the situation but 
made no effort to deal with it, since the employer cannot be expected to deal with the unknown. This is best illustrated in Ntsabo $v$ Real Security CC ((2003) 24 ILJ 2341 (LC)), wherein the employer was on several occasions made aware of the harassment of a female employee, but chose not to address the matter. This resulted in the employee resigning and claiming constructive dismissal. The court upheld the employee's claim. However, in Aldendorff $v$ Outspan International Ltd ((1997) 18 ILJ 810 (CCMA) 817A), an assertion was made that the applicant's resentment cannot be held sufficient to find the respondent responsible for making continued employment intolerable, especially if the respondent was unaware of the existence of such resentment or unhappiness (see also Coetzee $v$ The Citizen Newspaper (2003) 24 ILJ 622 (CCMA) 640-643; Eastern Cape Tourism Board v CCMA [2010] 11 BLLR 1161 (LC)).

\section{Objective test}

The test for constructive dismissal is an objective one (see Mafomane $v$ Rustenburg Platinum Mines supra; Johnson v Rajah supra and Smithkline Beecham v CCMA supra). However, the test is not only objective, but is set at a high standard (Van Niekerk et al Law@work 247). In a UK case, Woods $v$ WM Car Services (Peterborough) Ltd ((1982) IRLR 413 (CA) 415), the court held that circumstances of constructive dismissal are so infinitely various that there can be no rule of law stating what circumstances justify it and what do not. It is for the court to determine whether constructive dismissal has taken place. The court will do this after objectively examining the circumstances of each case. The court cannot just accept what the employee claims without any justification. It was held in Smithkline Beecham (Pty) Ltd v CCMA ((2000) 3 BLLR 344 (LC) 38) that the subjective apprehension of an employee cannot be the final determinant (see also Foschini Group v CCMA (2008) 29 ILJ 1515 (LC); Eagleton v You Asked Services supra). It is not the employee's perception of events that establishes intolerability, but the employer's conduct judged objectively (Van Niekerket al Law@work 247).

\section{The employee must exhaust all possible remedies before resigning}

In order for an employee to be successful in a claim of constructive dismissal in terms of section 186(1)(e) of the LRA, such employee must also prove that the termination of the relationship was the only available option (Grogan Workplace Law 152). This section does not expressly provide that termination must be the only option left for the employee nor does it provide a list of what could or may trigger the employee to terminate the employment relationship and claim constructive dismissal (NETU $v$ Meadow Feeds (1998) 1 BLLR 99 (CCMA) 105H); it states simply that the employee may terminate a contract of employment if the employer's conduct makes it difficult for the employee to continue to work. The requirement that the employee should claim constructive dismissal as a matter of last resort has developed into law through usage (see Jooste $v$ Transnet supra; Smith $v$ Magnum Security [1997] 3 BLLR 336 (CCMA)). In Jordaan v CCMA ([2010] 
12 BLLR 1235 (LAC)), Davis JA said the following regarding constructive dismissal:

"[c]onstructive dismissal is not for the asking. With an employment relationship, considerable level of irritation, frustration and tension inevitably occur over a long period. None of these problems suffice to justify constructive dismissal. An employee, such as appellant, must provide evidence to justify that the relationship has indeed become so intolerable that no reasonable option, save for termination is available to her."

With regard to the use of the word "intolerable" in section 186(1)(e) of the LRA, the commissioner in Smith v Magnum Security (supra) stated that the employer's conduct need not only be unreasonable or unfair but must have developed to the extent that it is intolerable for the employee to remain on (see Smithkline Beecham v CCMA supra; Mafomane v Rustenburg Platinum Mines supra). In other words, resignation must have become the only reasonable option. The above indicates that, in order for constructive dismissal to have occurred, the employee alleging it must be able to show that there was indeed intolerable conduct by the employer that left him or her with no option but to terminate the employment relationship. In Lubbe $v$ ABSA Bank Bpk ((1998) 12 BLLR 1224 (LAC)), an employee resigned and claimed to have been constructively dismissed. The court did not uphold his claim, citing that he had an opportunity to take the matter up or to lodge a formal grievance (see also Aldendorff $v$ Outspan International supra; Kruger $v$ CCMA (2002) 11 BLLR 1081 (LC)). This demonstrates that, had the employee exhausted the available processes before resigning, constructive dismissal would have been an appropriate claim.

In Pretoria Society for the Care of the Retarded $v$ Loots ((1997) 18 ILJ 981 984D), the court stated the following with regard to the principle of last resort:

"when an employee resigns or terminates the contract as a result of constructive dismissal such employee is in fact indicating that the situation has become so unbearable that the employee cannot fulfil his or her duties.

The employee is in effect saying that he or she would have carried on working indefinitely had the unbearable situation not been created. He does so on the basis that he does not believe that the employer will ever reform or abandon the pattern of creating an unbearable working environment. If she is wrong in this assumption and the employer proves that her fears were unfounded then she has not been constructively dismissed and her conduct proves that she has in fact resigned".

Similarly, in Copeland and New Dawn Prophesy Business Solutions (Pty) Ltd ((2010) 31 ILJ 204 CCMA 214A-B), the court held that the employee who raises constructive dismissal must show that the employer made continued employment so intolerable to him, to such an extent that he finally in desperation, having exhausted all internal mechanisms of the employer available to him, that he was left with no other viable alternative but to resign. In those instances, resigning would be appropriate. Notwithstanding that most decisions support the view that constructive dismissal must be a measure of last resort, a Constitutional Court judgment in Strategic Liquor Services v Mvumbi NO ((2009) 9 BLLR 847 (CC) par 4) indicated that it would suffice merely to prove that continued employment is intolerable. In Asara Wine Estate \& Hotel (Pty) Ltd v Van Rooyen ((2012) 33 ILJ 363 (LC)), 
the applicant, however, argued that the above remarks made in Strategic Liquor Services $v$ Mvumbi supra were obiter and should not be interpreted as disapproving of constructive dismissal being a measure of last resort. In qualifying his assertion, the applicant's representative pointed out that the Constitutional Court referred to authorities that support the principle of last resort and by doing so, it implies that the argument stands. The applicant argued further that to him the principle of last resort represents the correct statement of the law and remains unchanged by the dictum (Asara Wine Estate \& Hotel (Pty) Ltd v Van Rooyen supra 9-10). In this case, there were a number of options to be explored, but Van Rooyen resigned and claimed constructive dismissal. After referring to, among others, the finding in Chabeli v CCMA ((2010) 31 ILJ 1343 (LC) 52) and the circumstances surrounding the case before the court, Steenkamp $\mathrm{J}$ held that the court has to look at the situation objectively, and an employee has to be more robust and vigorous when there are still options open to him. What the court did was simply repeat the wording of section 186(1)(e) of the LRA, which on its own does not or would not help much if the facts are not interrogated objectively. The principle of last resort best serves this purpose and, beyond that, it prevents employees from becoming crybabies of the workplace (LM Wulfsohn Motors t/a Lionel Motors v Dispute Resolution Centre ((2008) 29 ILJ 356 (LC) 362D-G). In Van Greunen v Johannesburg Fresh Produce Market (Pty) Ltd ((2010) 7 BLLR 785 (LC)), the employee claimed that she was not considered for the newly advertised post of CEO and that she was removed from the executive floor to another office, which did not have a phone installed, until she made an enquiry. She also alleged that she was no longer being greeted; instead, a colleague aggressively brushed past her and gave her a filthy look and his whole attitude was totally unacceptable. Following the above allegations, the applicant alleged constructive dismissal. After an objective assessment of facts, Molahlegi $\mathrm{J}$ dismissed the claim. With regard to the non-greeting incident, it was held that there was no legal obligation to greet her and even if there were, the court lambasted her for not taking any reasonable step before resigning to establish the reason for the attitude that morning. In this regard, the court was re-affirming the principle of last resort. However, in Wulfsohn Motors $v$ Dispute Resolution Centre (supra), the court held that in certain instances the use of internal processes would just not be helpful and were therefore unnecessary; examples include when available procedures cannot be trusted or decisions are often pre-determined (see Strategic Liquor Services v Mvumbi supra; Dekker "Did He Jump or Was He pushed? Revisiting Constructive Dismissal" 201224 SAMLJ 346 349). In these instances however, it would follow that the employee must provide proof as to why available internal measures cannot be exhausted.

If the employee is able to prove all the above elements, then there is a prima facie case of constructive dismissal against the employer, and the onus shifts to the employer who should rebut the employee's case. In Pretoria Society for the Care of the Retarded v Loots (supra), the court held that the enquiry is whether the employer, without reasonable and proper cause, conducted itself in a manner calculated or likely to destroy or seriously damage the relationship of confidence and trust between the employer and employee. It further stated that it is the court's function to look 
at the employer's conduct as a whole and determine whether its effect, judged reasonably and sensibly, is such that the employee cannot be expected to put up with it.

It is evident from the above that intolerable circumstances caused by the employer are key to a successful claim of constructive dismissal by an employee. These circumstances must be so critical that they made it difficult for the employee to continue working and as a result the employee resigned because he or she tried everything to resolve the matter, without success.

\section{Remedies for unfair dismissal in South Africa: reinstatement, re-employment and compensation}

If it is found that the employee has been dismissed and that the dismissal was unfair, the question of remedies arises. Under the LRA, the remedies for unfair dismissal are provided for under section 193(1) as follows:

"If the Labour Court or an arbitrator appointed in terms of this Act finds that a dismissal is unfair, the Court or the arbitrator may-

(a) order the employer to reinstate the employee from any date not earlier than the date of dismissal;

(b) order the employer to re-employ the employee, either in the work in which the employee was employed before the dismissal or in other reasonably suitable work on any terms and from any date not earlier than the date of dismissal; or

(c) order the employer to pay compensation to the employee."

In terms of the above section, the court or the arbitrator must first find that the dismissal was unfair before ordering any of the mentioned remedies. Where, for example, the employee was employed under a fixed-term contract and there was no reasonable expectation of renewal, the termination of employment will not amount to an unfair dismissal (Naidoo $v$ Portnet (1997) 18 ILJ 1109 (CCMA)). The court or arbitrator may order reinstatement, re-employment or compensation. The wording of the section implies that reinstatement is the primary statutory remedy for unfair dismissal, followed by re-employment (see The Explanatory Memorandum to the Labour Relations Bill, Ministerial Legal Task Team, January 1995 par 44; Basson and Strydom "The Labour Relations Act 66 of 1995: The Resolution of Disputes About Alleged Unfair Dismissals" 19968 SA Merc LJ 1 16; Van Niekerk "Remedies for Unfair Dismissal" 1996 6(4) Contemporary Labour Law 31 32).

The distinction between reinstatement and re-employment is not always so clear and the LRA does not define either of the two concepts. On the one hand, a reinstatement order restores the contractual position between the employer and the employee as if it had never been broken (SEAWU $v$ Trident Steel (1986) 7 ILJ 418 (IC) 437F). An employee's rights, such as seniority, stay the same. Anderman defines reinstatement as "an order that the employer restores the employee to his former position treating him in all respects as if he had never been dismissed" (The Law of Unfair Dismissal 3ed (2001) 334). The employer must also pay an employee the remuneration that would have been due had his employment not been terminated (Consolidated Frame Cotton Corporation Ltd $v$ President of the 
Industrial Court 1986 (3) SA 786 (A)). Reinstatement therefore maintains the status quo. In Equity Aviation Services (Pty) Ltd v CCMA ([2008] 12 BLLR 1129 (CC)), the Constitutional Court explained the word "reinstate" as follows:

"The ordinary meaning of the word 'reinstate' is to put the employee back into the job or position he or she occupied before the dismissal, on the same terms and conditions. Reinstatement is the primary statutory remedy in unfair dismissal disputes. It is aimed at placing an employee in the position he or she would have been but for the unfair dismissal. It safeguards workers' employment by restoring the employment contract. Differently put, if employees are reinstated they resume employment on the same terms and conditions that prevailed at the time of their dismissal."

On the other hand, a re-employment order imposes a new relationship, which may be different from the old one. It implies termination of the previous employment relationship and the creation of a new one on new terms (see Du Toit et al Labour Relations Law 525; NUM v Haggie Rand Ltd (1991) 12 ILJ 1022 (LAC) $1027 \mathrm{E}-\mathrm{J}$ ). In cases where the employee is reemployed in the old job, it will be without the rights, such as seniority, previously acquired in the old job (Basson et al Essential Labour Law 401). Where an employee is given a different job, section 193(1)(b) of the LRA states that it must be "reasonably suitable work".

Under circumstances where the Labour Court or the arbitrator may not order the above two remedies, compensation may be ordered. Compensation may also be ordered where the dismissal was found to be only procedurally unfair (s 193(2) of the LRA). Section 194 of the LRA sets a maximum amount of compensation that the Labour Court or the arbitrator may order. Compensation is calculated on the basis of the employee's remuneration on the date of dismissal. Section 213 of the LRA defines "remuneration" as "any payment in money or in kind, or both in money and in kind, made or owing to any person working for any other person including the State".

The discussion that follows focuses on reinstatement as a remedy for constructive dismissal and determines whether it is an appropriate remedy, given that the employee terminates the employment contract owing to intolerable circumstances whereas reinstatement restores the employee to the position at the time of the dismissal.

\section{To order or not to order reinstatement in cases of constructive dismissal}

Reinstatement as a primary remedy for unfair dismissal was previously provided for in terms of section 46(9) of the Labour Relations Act 42 of 1956. This section required the Industrial Court to determine the dispute on such terms as it deemed reasonable, including but not limited to the ordering of reinstatement or compensation. The choice of an appropriate remedy fell under the discretion of the Industrial Court. However, it seems under the LRA there is limited discretionary power on which remedy to order. Reinstatement or re-employment must be ordered in all cases of unfair 
dismissal unless under circumstances prescribed by the LRA in section 193(2), which states as follows:

"The Labour Court or the arbitrator must require the employer to reinstate or re-employ the employee unless-

(a) the employee does not wish to be reinstated or re-employed;

(b) the circumstances surrounding the dismissal are such that a continued employment relationship would be intolerable;

(c) it is not reasonably practicable for the employer to reinstate or re-employ the employee; or

(d) the dismissal is unfair only because the employer did not follow a fair procedure."

Based on this provision, reinstatement should not be ordered where the employee does not wish to be reinstated (Adams $v$ Coin Security Group (Pty) Ltd [1998] 12 BLLR 1238 (LC)), or if continuation of the employment relationship would be intolerable, or where it is not reasonably practicable for the employer to reinstate the employee, or where the dismissal had been unfair only in a procedural sense (Malelane Toyota v CCMA ([1999] 6 BLLR 555 (LC)). In Kroukam v SA Airlink (Pty) Ltd ([2005] 12 BLLR 1172 (LAC)), the Labour Appeal Court confirmed that a court or arbitrator has no discretion not to award reinstatement or re-employment unless one of the listed factors is present.

In New Clicks SA (Pty) Ltd v CCMA ((2008) 29 ILJ 1972 (LAC)), the court held that the provisions of section 193(2) of the LRA should be sparingly invoked and the primary remedy of reinstatement should only be refused after careful consideration of all relevant circumstances. In National Union of Metalworkers of SA v Henred Fruehauf Trailers (Pty) Ltd ((1995) 4 SA 456 (AD) 16), the court stated that "[w]here an employee has been unfairly dismissed he suffers a wrong. The fullest redress obtainable is provided by the restoration of the status quo ante. It follows that it is incumbent on the court when deciding what remedy is appropriate to consider whether in the light of all the proved circumstances there is reason to refuse reinstatement" (see also National Construction \& Building Workers Union v MF Woodcraft (Pty) Ltd (1997) 18 ILJ 165 (LAC)). It has been held that the overriding principle in all cases should be fairness and job security, as opposed to the legal onus each party carried (see Dunwell Property Services CC v Sibande (2012) 2 BLLR 131 (LAC); NUMSA obo Maifo v Ulrich Seats (Pty) Ltd (2012) 33 ILJ 2918 (LC) 2929; Du Toit et al Labour Relations Law 526).

\section{The employee wishes not to be reinstated}

Although an order of reinstatement for unfair dismissal may be made, section 193(2) of the LRA requires the court or arbitrator first to determine the wishes of the employee. The employee who chooses not to be reinstated must therefore not be forced to return to his job (Ntsibande $v$ Union of Carriage \& Wagon Co (Pty) Ltd (1993) 14 ILJ 1566 (IC) 1227). In Adams v Coin Security Group (Pty) Ltd ((1999) 20 ILJ 212 (LC)), it was held that reinstatement cannot be granted to applicants who do not wish to be reinstated, whereas, in Van Zyl v Plastafrica (Pty) Ltd ((1999) 20 ILJ 212 (LC)), it was held that an employee who has been dismissed without a fair 
reason is only entitled to refuse an offer of reinstatement on reasonable grounds (see also Burger v Alert Engine Parts (Pty) Ltd [1999] 1 BLLR 18 (LC); Johnson \& Johnson (Pty) Ltd v CWIU [1998] 12 BLLR 1209 (LAC)). However, in Western Cape Education Department $v$ Julian ((2013) 8 BLLR 834 (LC)), it was stated that it is anomalous for an employee who claims constructive dismissal, alleging that the employer made the working relationship intolerable, to come back and claim reinstatement.

\section{Circumstances surrounding the dismissal would make continued employment relationship intolerable}

The determination in a constructive dismissal case is whether a continued working relationship between the parties will be tolerable under the circumstances that led to the dismissal. In Performing Arts Council of the Transvaal v Paper Printing Wood \& Allied Workers Union (1994 (2) SA 204 (A) $219 \mathrm{~A}-\mathrm{C}$ ), it was held that, in considering whether circumstances are tolerable or intolerable before ordering a particular remedy, the correct approach was to give due consideration to the conduct of the parties and, in the light of that, decide on the appropriate relief. The words used in section $193(2)(b)$, "if circumstances surrounding the dismissal are such that continued employment relationship would be intolerable", are similar to those used in section 186 of the LRA for constructive dismissal.

The test to be applied is the one developed in Woods $v$ WM Car Services (Peterborough) (supra), where it was stated that what is required is a consideration of the employer's conduct as a whole and a determination of whether it is such that its effect, judged reasonably and sensibly, is that the employee cannot be expected to put up with it. The circumstances relevant for the determination as required by section 193(2)(b) of the LRA may also include the employee's conduct, the nature of the relationship between the employer and the employee, the degree of hostility or animosity between them at the time of dismissal and prospects of a constructive employment relationship in future (Van Niekerk 1996 CLL 33-34). It was held in Kroukam $v S A$ Airlink (supra) that mere allegations that the employment relationship had broken down and that continued employment was not feasible were not sufficient. The emphasis in terms of section 193(2)(b) of the LRA is on the circumstances surrounding the dismissal; therefore, if circumstances surrounding the dismissal have changed since the dismissal, the employee may be reinstated.

The following was stated in National Construction \& Building Workers Union v MF Woodcraft (Pty) Ltd supra 173) with regard to a continued working relationship:

"That the respondent regarded a future working relationship with the appellant as intolerable was clear. That is why it tried three times to dismiss him. Its attitude, although relevant, cannot be determinative of whether there is 'reason to refuse reinstatement'. The reasons it gave, namely fraudulent conduct, and disruptiveness, were held to lack substance. What of tolerableness from the second appellant's point of view? He may safely be assumed to be a resilient individual, whose sensitivities will survive the slight of having been unjustly dismissed three times. His persistence in seeking 
reinstatement indicates that he, certainly will not find the future working relationship intolerable."

An employee who seeks reinstatement as a remedy for constructive dismissal must prove that the intolerable circumstances no longer exist at the workplace. In Western Cape Education Department $v$ Julian (supra), the employee referred a dispute to the CCMA, alleging constructive dismissal. The arbitrator found that the employee should be reinstated and on review the court agreed with that finding and held that, based on the employee's uncontested evidence, the circumstances at the time of the arbitration were not the same as at the time of the employee's resignation. In Asara v Van Rooyen (supra), it was stated that, for purposes of constructive dismissal, an employee terminates the contract of employment on the basis that the situation has become so unbearable that the employee can no longer fulfil his or her duties. This is done under the belief that the employer will never abandon the pattern of creating an unbearable work environment. Each case must be dealt with based on its merits. However, the question is whether, if the employee is reinstated, the parties will be able to continue with a normal employment relationship.

\section{Not reasonably practicable to reinstate}

The term "practicable" was interpreted in Dedman $v$ British Building \& Engineering Ltd ([1974] 1 All ER 520 (CA) 528) as "an ordinary English word of great flexibility" which "takes its meaning from its context" and which, whenever it is used, "is a call for the exercise of common sense, a warning that sound judgment will be impossible without compromise". The question of reasonableness will require the court or the arbitrator to make an objective value judgment (NUMSA v Vetsak Co-operative Ltd (1996) (4) SA 577 (A)). In cases where the employer has already found a replacement for the position, reinstatement will not be practicable. The closure of a business is another sign that reinstatement is not practicable. The court could not reinstate dismissed employees in Ellias $v$ Germiston Uitgewers (Pty) Ltd t/a Evalulab ((1998) 19 ILJ 314 (LC)) because the employer had closed down the business. The employer's financial circumstances may also be relevant in this regard (SA Commercial Catering \& Allied Workers Union $v$ Steers Fast Food (1993) 14 ILJ 378 (LAC)). Where the employee had to relocate for personal reasons, it was also found that reinstatement would not be appropriate (Van Tonder $v$ International Tobacco Co [1997] 2 BLLR 254 (CCMA)). It will also not be practical to order reinstatement where it would be unlawful for the employer to comply with the order because of the operation of a statute. It was held in A Venter $v$ Ozalid SA (Pty) Ltd ((1993) 4(2) SALLR 25 (IC)) that an employee who is aware that the position he had no longer exists could not ask to be reinstated.

\section{Dismissal only procedurally unfair}

In cases where a dismissal is found to be only procedurally unfair, the only remedy that can be ordered is compensation (see Malelane Toyota $v$ CCMA supra; Du Toit et al Labour Relations Law 526). 


\section{Constructive dismissal in the United Kingdom}

\section{Constructive dismissal}

In terms of section 95(1)(c) of the UK's Employment Rights Act, 1996 (ERA), an employee is dismissed by the employer if "the employee terminates the contract under which he is employed (with or without notice) in circumstances in which he is entitled to terminate it without notice by reason of the employer's conduct". An employee who resigns in such circumstances is deemed to have been constructively dismissed. In other words, similar to the South African position, it is the employee who terminates the contract owing to circumstances caused by the employer's conduct. This termination emanates from a breach of the term of trust and confidence that is inherent in a contract of employment (Malik $v$ Bank of Credit and Commerce International SA [1997] UKHL 23). It has been stated that in order for a tribunal to rule that there is constructive dismissal, the employer's action or conduct must be a significant breach of the contract (British Leyland UK Ltd $v$ McQuilken [1978] IRLR 245), indicating that the employer intends no longer to be bound by one or more terms of the contract. This will amount to repudiation of the contract by the employer.

This may take place where the employer has, for example, arbitrarily demoted an employee to a lower position or a lower-paid position (www.berr.gov.uk/employment/employment-legislation/employment-

guidance/page31082.html\#Constructive_dismissal (accessed 2018-05-22)). In the UK, there are two types of constructive dismissal - that is, commonlaw and statutory constructive dismissal. Under common law, if there is an acceptance of a repudiation of the contract, then there will be constructive dismissal (see Western Excavating (ECC) Ltd v Sharp [1978] ICR 221; Lewis v Motorworld Garages Ltd [1986] ICR 157). However, for purposes of a statutory constructive dismissal, the requirement is that the employer's conduct causes the employee to terminate the contract (s 95 of the ERA). Classic causes of constructive dismissal in the UK include the following: unilateral changes to the contract of employment by the employer, such as a deliberate cut in pay (Cantor Fitzgerald International v Callaghan [1999] ICR 639); refusal of holiday (Lytlarch Ltd v Reid [1991] ICR 216); and suspension with or without pay (William Hill Organisation Ltd v Tucker [1999] ICR 291). Breach of contract in the form of bullying, such as ignoring complaints (Goolds v McConnell [1995] IRLR 516), and criticism in front of subordinates (Hilton International Hotels (UK) Ltd $v$ Protopapa [1990] IRLR 316) may also result in a claim of constructive dismissal by the employee.

The employer's conduct in this regard could be a once-off serious breach of contract, or anything to the employee's detriment that is a last straw (Logan v Commissioners of Custom and Excise [2004] IRLR 63) after a string of serious breaches (Abbey National plc v Robinson [2001] IDS Brief $680)$. The employee's resignation should take place within a reasonable time of the last straw (Jones v F Sirl \& Son (Furnishers) Ltd [1997] IRLR 119). Although the last straw should be related to the obligation of trust and confidence, it (the last straw) need not be similar to earlier events but when 
added to earlier events it must be enough to constitute a repudiation (Omilaju v Waltham Forest London Borough Council [2005] ICR 481).

\section{Remedies for unfair dismissal}

In the case of an unfair dismissal, including constructive dismissal, a complaint may be presented to an industrial tribunal against an employer (s 111 of the ERA). The tribunal is required to explain to the complainant what orders may be made under section 113 and in what circumstances they may be made and further ask him whether he wishes the tribunal to make such an order and if he makes such a wish the tribunal may make an order of reinstatement. If no order is made, the tribunal will award compensation for unfair dismissal, which is calculated in terms of sections 118-127 of the ERA and is to be paid to the employee by the employer. An order under section 113 may be an order of reinstatement (s 114 of the ERA) or an order for re-engagement (s 115 of the ERA).

Similar to the position in South Africa, reinstatement in terms of section 114 implies that the employer should treat the complainant in all respects as if he had not been dismissed. The tribunal must specify any amount payable by the employer in respect of any benefit that the complainant might reasonably be expected to have had but for the dismissal; any rights and privileges that must be restored to the employee; and the date by which the order must be complied with. In exercising its discretion under section 113, the tribunal must, similarly to the position under the LRA, first consider certain factors such as whether the complainant wishes to be reinstated; whether it is practicable for the employer to comply with an order for reinstatement; and where the complainant caused or contributed to some extent to the dismissal, whether it would be just to order his reinstatement.

\section{$5 \quad$ Evaluation and conclusion}

Although reinstatement is a primary remedy for unfair dismissal, it must be noted that constructive dismissal is unique in nature as the termination of employment is initiated by an employee who claims intolerable circumstances in the employment relationship (see Grogan Workplace Law 152; Eagleton v You Asked Services supra; Solid Doors v Commissioner Theron supra). Constructive dismissal is peculiar because it is the employee, rather than the employer, who terminates the employment contract and alleges dismissal. As discussed above, for purposes of constructive dismissal, the employee must prove that it was indeed a dismissal and not a resignation. Proving constructive dismissal is not easy and it requires much more than mere personal feelings of frustration or tension between the parties (Jordaan v CCMA supra 1239). Constructive dismissal is proved if the employee shows objectively that the employer made continued employment intolerable and that as a result, the employee was left with no option but to resign (see Mafomane $v$ Rustenburg Platinum Mines supra; Grogan Workplace Law 152). The termination of employment by the employee in these circumstances is to a large extent based on the belief that there was no other alternative as the employer was not prepared to relinquish the attitude that created intolerable circumstances (Pretoria 
Society for the Care of the Retarded $v$ Loots supra 984E). The position in the UK is that conduct by the employer should have been a last straw (Logan $v$ Commissioners of Custom and Excise supra) causing detriment to the employee and that it resulted in the employee terminating the employment contract. This emanates from a serious breach of the term of trust and confidence inherent in a contract of employment (Malik v Bank of Credit and Commerce supra).

Given the above, the remedy of reinstatement seems contrary to assertions of constructive dismissal. In its nature, the remedy of reinstatement restores the contractual position between the employer and the employee as if it had never been broken (see SEAWU v Trident Steel supra; Anderman The Law of Unfair Dismissal 334). Therefore, prima facie, reinstatement does not seem to be an appropriate remedy for constructive dismissal, especially in cases where constructive dismissal emanated from issues related to the position and terms and conditions to which the employee must be restored (for example, a lower position or lower salary than the original one). If the position to which the employee is restored is the one that led to the termination of employment, this could be problematic. In such a case then, the employee should be restored to the position prior to the one at the time of dismissal.

Nevertheless, it is evident from the discussion above that the drafters of the LRA had a clear intention to protect and ensure the job security of employees through this remedy. This can also be seen from the provisions of section 193(2), which states that "the Labour Court or the arbitrator 'must' require the employer to reinstate ... the employee". It should be stated that the word "must" is used to express an obligation or imperative requirement, which means that the court or the arbitrator has an obligation to order reinstatement as a primary remedy. The phrasing of section 193(2) shows that in South Africa, unlike in the UK, the court or the arbitrator's discretion in deciding which remedy to order is limited, unless the exceptions mentioned therein exist (see Kroukam v SA Airlink supra; Visser v Mopani District Municipality [2012] 3 BLLR 266 (SCA)). To further support this, it has been held that if a remedy of reinstatement is not granted, reasons should be provided for not granting it (Ethekhwini Municipality $v$ Hadebe [2016] 8 BLLR 745 (LAC)).

The exceptions stated in section 193(2) may, however, also raise challenges - for example, where the employee does not want to be reinstated, but according to the court or arbitrator, reinstatement seems fair to both the employee and the employer; or where the employee or employer argues that a continued employment relationship is not practical due to the strained relationship between the parties (Grogan Dismissal 3ed (2017) 715-716); or if the degree of hostility or animosity between them at the time of dismissal is high. If the employee has somehow contributed to the dismissal, that may also raise some challenges as this is one of the factors that may be considered when ordering reinstatement as a remedy (see Van Niekerk 1996 CLL 33-34; s 113 of the ERA). In Matsekoleng v Shoprite Checkers (Pty) Ltd ([2013] 2 BLLR 130 (LAC)), the Labour Appeal Court found that reinstatement may not be granted when an employment 
relationship is rendered unsustainable by the employee's allegations against his or her superiors.

In considering a remedy for constructive dismissal, the court or arbitrator should therefore be guided by what is fair in the circumstances (see Dunwell Property Services $v$ Sibande supra; NUMSA obo Maifo $v$ Ulrich Seats supra). Courts and arbitrators should have a wider discretion on which remedy to order, especially in constructive dismissal cases, given the nature of this dismissal. The court or arbitrator should carefully consider all factors and circumstances before ordering a remedy. Employers should, however, also be careful not deliberately to cause intolerable circumstances for employees, thinking that reinstatement will not be ordered, as was the case in Western Cape Education Department v Julian (supra).

KL Kubjana

University of South Africa (UNISA)

ME Manamela

University of South Africa (UNISA) 